\title{
Shielding the Unitary Patent from the ECJ: A Rash and Futile Exercise
}

\author{
Thomas Jaeger
}

Published online: 24 May 2013

(C) Max Planck Institute for Intellectual Property and Competition Law, Munich 2013

The long-promised patent package for the EU has finally come into being by virtue of Decision 2011/167/EU (enhanced cooperation), Regulations 1257/2012 (substantive law) and 1260/2012 (translation arrangements) and of the Unified Patent Court Agreement signed last January (Council Document 16351/12). Whether it will also enter into force remains to be seen. Requirements are the ratification of the Agreement by thirteen signatories (none deposited so far) and an amendment of the Brussels I Regulation (1215/2012) to accommodate the new Court. Also, despite the Council's best efforts to bring the Regulation within Art. 142 EPC, an accession of the EU to the EPC may yet be necessary: The EU legislator is a body different from the EPC states meeting in the Council and cannot partake in an Art. 142-type agreement. Furthermore, while the Court has recently turned down two actions directed against the legality of enhanced cooperation in joined cases C-274/11 and C-295/11, two fresh actions for annulment relating to the two Regulations are now pending with the ECJ (Cases C-146/13 and C-147/13). Even if latter should likewise not succeed to mar or delay implementation, more litigation is on the horizon as the package's individual measures unroll. The compatibility of the Agreement with EU law (ECJ Opinion 1/09 in particular) could be tested by infringement actions under Art. 259 TFEU, directed against the participating Member States. Also after implementation, the legality of the two Regulations and the Agreement might bounce back to the ECJ via requests for preliminary rulings posed by national courts doubtful as to the EU law compatibility of the package's measures. The Rau line of case law allows individuals to contest implementing measures for EU acts before a national court on invalidity grounds. Under the FotoFrost line of case law, national courts of any level are actually strictly obliged to interrupt proceedings and lodge a

T. Jaeger $(\bowtie)$

PD Dr., LL.M. (K.U. Leuven); Senior Research Fellow

Max Planck Institute for Intellectual Property and Competition Law,

Marstallplatz 1, 80539 Munich, Germany

e-mail: Thomas.Jaeger@ip.mpg.de 
preliminary reference if they harbor validity doubts. The persistence of such doubts will not least depend on the depth of the ECJ's reasoning in the currently pending cases.

Given the ifs and pitfalls still ahead, the patent for the internal market is still no done deal - and that may not be a reason for gloom. Readers of this law journal in particular will not have missed that the package as it now stands is an appalling caricature of the original plans and accordingly has taken heavy criticism for its systemic complexity, persisting territorial and legal fragmentation, an unbalanced and anachronistic design, and for yielding inacceptable legal and economic uncertainties for users. Put simply, the unitary patent system is a bad system in terms of its likely effects for the functioning of the internal market and for innovation. Rather than hoping for it to come into operation any time soon, we should hope for it to be substantially re-thought and re-modeled once more.

Still, it is not so much any of the individual flaws of design that make the patent package most remarkable, but rather the systemic change - or rather, breach? - that it brings about in EU IP law. The unitary patent is in no way like any of the currently existing the types of IP rights for the internal market. The EU's systems for trade marks, designs and plant variety protection are all comprehensive bodies of legislation, establishing regimes which are complete as regards, in particular, the rules on the requirements and scope of protection and on exceptions and limitations, and with framework rules for the property aspects of the right and for its crossborder enforcement in the case of infringement. The individual rights accorded under these regimes boast a sui generis character in terms of their autonomy vis-àvis national law and upon their enforcement benefit from the EU law's general principles of primacy, equivalence and effectiveness.

The unitary patent will be nothing like that: It is not autonomous in terms of an independence from third law. Rather, patent protection is grafted upon the EPO decision to grant the patent bundle. The EU right thus hinges upon the existence and validity of that non-EU law act. This legal technique is unique in EU law and may well be incompatible with its primacy principle. Even more importantly, the Regulation does also not delineate the shape of the right accorded. The requirements of protection and exceptions are laid down in the EPC (to which the EU is not yet a member), while all limitations are left to the national laws. The scope of protection is therefore not determined in the Regulation. Instead, a detour is made to the Court Agreement, where the infringing acts falling within the Court's jurisdiction are laid down. The harmonization of the patent scope necessary for the operation of the system is thus only introduced through the backdoor of international law. Again, this legal technique may encounter several problems with EU law, starting with primacy and the evasion of EU legislative competences. It does also not seem to fit Art. 118 TFEU as the legal basis chosen for the Regulation: Whereas sui generis IP systems for the internal market warrant a comprehensive approach in determining the characteristics of the right, the harmonization of only some aspects of protection of rights otherwise rooted in national law is a classic characteristic of internal market legislation under Art. 114 TFEU. In short, in contrast to the existing IP rights for the internal market, the unitary patent is markedly trimmed in terms of an export of all of its essential features outside the EU legal order. 
The fascinating question at the bottom of all this is, why? Why did the EU legislator resort to such unusual and arguably legally deficient techniques to create an EU IP right, while at the same time trying to avoid as much of the EU legal order as possible (something, by the way, we also observe in the design of the Patent Court). Did necessities of Opinion 1/09 force it to do so? Was it the shift to enhanced cooperation? In both instances, the answer is negative. Opinion 1/09 did not even deal with substantive patent law, whereas enhanced cooperation is, already by virtue of Art. 20(1) TEU, without prejudice to the form and harmonizing intensity of the measures enacted under the cooperation.

The answer is much simpler: The aim is to avoid the ECJ's jurisdiction in interpreting patent law. Recent years have seen repeated outbursts of mistrust among certain segments of the patent community's practitioners against the ECJ's professional aptitude to assess matters of patent law. Not least, this was an important reason behind the failure of the 2004 centralized (Art. 257 TFEU-style) patent court proposal. It may well be that Opinion 1/09, although legally dealing with something else, may have sent another signal that excessive jurisdictional powers of the ECJ were on the horizon and that that Court held no understanding for the necessities of patent practice. Be that as it may, sometime between mid-2011 and mid-2012 forces calling for a complete shut-off of the system vis-à-vis the ECJ gained the upper hand in Council discussions. The best means to ensure that the ECJ would never have a decisive say in the interpretation of substantive patent law was seen in keeping the Regulation as slim and brief as possible and thereby give the ECJ as few provisions of EU law as possible to interpret should it ever be concerned with a patent case.

Few will disagree that the ECJ can point to an overall outstanding jurisdictional record over the last 60 years of European integration. Without its prominent role for a proactive advancement of the body of EU law, Europe would not be where it is today. Isn't it remarkable that precisely in the area of patent law, this Court is so bitterly mistrusted and fought? Why would we want to introduce patent protection into the EU framework to reap the benefits of that regime, but at the same time defy the Court that is largely responsible for the success of its legal framework? Why would we take such pains to avoid that Court, so as to even venture into the most dubious legal constructs? This cannot be termed anything but schizophrenic and foolish.

It remains to be seen whether the ECJ will see through this charade in the cases currently before it. Anyhow, the exercise will hardly yield the desired shielding effect. It is naïve to believe that the ECJ would refrain from filling-in the blanks left in the Regulation if needed to ascertain the extent of individual legal protection under it. After all, EU law is autonomous, determined by the rule of law and incorporates a complete system of remedies for legal protection. As cases as old as van Gend and Costa already tell us, combining these features means that the ECJ actually has more room for proactive law-making where an act contains blanks than where it states guidelines. The only real alternative to such proactivism would be for the ECJ to declare the Regulation void for lack of determination. 